\title{
KESESUAIAN PENGASUHAN PERUSAHAAN MULTIBISNIS: STUDI KASUS KELOMPOK BISNIS "MEDIA GROUP”
}

\author{
Ningky Sasanti Munir \\ PPM School of Management \\ nky@ppm-manajemen.ac.id
}

\begin{abstract}
The strategic objective of a multi-business firm is to generate firm value that exceeds the sum of the values of its strategic business units. Parent company can facilitate the value-creation of multi-business firm trough "parenting" activity. Previous studies show that higher compatibility between parent companies' parenting style and subsidiaries' needs likely generates higher firm values. Accordingly, this research aims to investigate the fit between parenting style of the parent company and subsidiaries' needs of Media Group (MG) as a multi-business firm that engages in media business. I obtain our primary data by conducting interviews with directors of the parent company and subsidiaries. In addition, I also support my interview data by analyzing the firm's internal documents and information from the firm's external environment. I classify the results into four categories, namely parent company's characteristics, critical success factors of subsidiaries, parenting opportunities, and parenting fit matrix. The results show that 15 or all subsidiaries are heartland or edge of heartland businesses; implying high fit between parent company's characteristics, critical success factors of subsidiaries, and existing parenting opportunities. Although the firm as a whole exhibits a parenting fit, there are two subsidiaries that still underperform.
\end{abstract}

Keywords: multibusiness company, value creation, parent company, parenting fit matrix.

\begin{abstract}
ABSTRAK
Sasaran perusahaan multibisnis adalah menciptakan nilai lebih dari sekedar penjumlahan nilai yang diciptakan seluruh unit-unit bisnis stratejik. Kreasi nilai di perusahaan multibisnis dapat dicapai melalui "pengasuhan" dari perusahaan induk. Studi terdahulu menunjukkan, semakin sesuai pengasuhan perusahaan induk dengan kebutuhan perusahaan anak, semakin besar nilai yang diciptakan. Oleh sebab itu dilakukan penelitian yang bertujuan untuk menentukan kesesuaian pengasuhan antara perusahaan induk dan perusahaan-perusahaan anak. Penelitian dilakukan di perusahaan multibisnis, "Media Group" (MG) yang bergerak di bidang media. Penelitian ini adalah penelitian kualitatif terapan yang menggunakan pendekatan studi kasus. Data primer diperoleh terutama melalui wawancara dengan direksi perusahaan induk dan perusahaan-perusahaan anak. Data sekunder diperoleh melalui kajian dokumen internal perusahaan dan informasi dari lingkungan eksternal perusahaan. Hasil penelitian dikelompokkan dalam empat kategori, yaitu karakteristik perusahaan induk, faktor sukses kritis perusahaan-perusahaan anak, peluang-peluang pengasuhan,
\end{abstract}


dan matriks kesesuaian pengasuhan. Hasil penelitian menunjukkan bahwa saat ini 15 atau seluruh perusahaan anak merupakan bisnis heartland dan edge of heartland yang berarti terdapat kesesuaian yang tinggi antara karakteristik perusahaan induk, faktor sukses kritis perusahaan anak, dan peluang-peluang pengasuhan yang ada. Walau terdapat kesesuaian pengasuhan, terdapat dua perusahaan anak yang tidak menunjukkan kinerja yang memuaskan.

Kata Kunci: perusahaan multibisnis, kreasi nilai, perusahaan induk, matriks kesesuaian pengasuhan.

\section{PENDAHULUAN}

Goold dan Campbell (2002) memaparkan bahwa perusahaan multibisnis adalah perusahaan yang memiliki dan mengelola banyak perusahaan dalam berbagai macam bisnis. Dalam perjalanannya perusahaan multibisnis berusaha terus bertumbuh, menciptakan nilai yang semakin besar dan lebih tinggi dibandingkan biaya dan investasi yang dikeluarkan untuk beroperasi (Basu 2010; Landau dan Bock 2013). Manfaat pertumbuhan tersebut tidak saja sekedar penjumlahan nilai dari seluruh unitunit bisnis strategik, melainkan jauh di atasnya.

Keberhasilan perusahaan multibisnis menciptakan nilai bergantung pada peran perusahaan induk dan kondisi yang ada (Basu 2010; Campbell et al., 1995; Ciabuschi et al., 2016). Terdapat tiga kondisi dimana perusahaan induk dapat mempengaruhi unit-unit bisnis stratejik dalam menciptakan nilai. Pertama, perusahaan menunjukkan kinerja yang kurang baik dan dapat diperbaiki (Campbell et al., 1995; Ciabuschi et al., 2016). Kalau perusahaan anak beroperasi dengan kinerja yang baik atau optimal, maka perusahaan induk tidak dibutuhkan. Dengan demikian perusahaan induk dapat mempengaruhi perusahaan anak untuk menciptakan nilai bila ada peluang untuk pengasuhan (parenting).

Kedua, perusahaan induk harus memiliki kemampuan atau sumber daya yang dibutuhkan untuk meningkatkan kinerja perusahaan anak (Ciabuschi et al., 2016; Landau dan Bock 2013). Dengan demikian peluang pengasuhan dapat dimanfaatkan sebaik-baiknya oleh perusahaan induk dan perusahaan anak untuk menciptakan nilai.

Ketiga, perusahaan induk harus memahami faktor-faktor sukses kritis perusahaan anak (Goold dan Campbell 2002; Ciabuschi et al., 2016). Dengan demikian perusahaan induk dapat mempengaruhi perusahaan anak dengan cara dan di bagian yang tepat. Campbell et al. 1995 serta Ciabuschi et al. 2016 menegaskan bahwa tanpa kondisi yang sesuai, perusahaan induk bukan saja tidak bisa mempengaruhi perusahaan anak untuk menciptakan nilai, bahkan dapat menghancurkan perusahaan anak. Seperti yang disampaikan oleh Campbell et al. 1995, kesesuaian pengasuhan atau parenting fit yang membuat perusahaan induk dapat menciptakan nilai bagi korporasi adalah apabila ketiga kondisi yang diuraikan sebelumnya itu ada dan dimanfaatkan baik oleh perusahaan induk maupun perusahaan-perusahaan anak. 
Penelitian ini ditujukan untuk mengetahui gambaran penerapan strategi pengasuhan korporat yang dilaksanakan saat ini, khususnya kesesuaian pengasuhan pada sebuah perusahaan multibisnis, yaitu Media Group (selanjutnya disebut sebagai MG). Selain karena alasan bahwa MG adalah sebuah perusahaan multibisnis, MG merupakan kelompok bisnis media terintegrasi terbesar di Indonesia. Dari hanya satu stasiun televisi berita tahun 1989, pada tahun 2016 MG telah berkembang menjadi kelompok bisnis dengan satu perusahaan yang berperan sebagai perusahaan induk (holding company) dan 15 unit bisnis stratejik atau perusahaan anak dengan kepemilikan induk minimal 70 persen. Melalui penelitian ini akan dijelaskan bagaimana kesesuaian pengasuhan perusahaan induk MG dengan perusahaanperusahaan anaknya.

Pemikiran Campbell et al. 1995 mengenai kesesuaian pengasuhan dipandang sebagai hasil pemikiran yang membantu para akademisi memahami hubungan antara perusahaan induk dan perusahaan-perusahaan anak, khususnya dalam hal kreasi nilai di perusahaan multibisnis. Namun dalam praktiknya, kesesuaian pengasuhan relatif sulit diterapkan karena operasionalisasi faktor-faktornya (Kruehler et al., 2012). Penelitian pada perusahaan multibisnis MG diharapkan dapat memperoleh pemahaman yang lebih mendalam mengenai garis besar faktor-faktor yang digunakan untuk mengetahui kesesuaian pengasuhan perusahaan induk dan perusahaanperusahaan anak.

Penelitian mengenai perusahaan multibisnis di Indonesia relatif langka karena keterbatasan akses informasi mengenai perusahaan (Munir 2010). Walau banyak perusahaan multibisnis di Indonesia merupakan perusahaan publik, namun memperoleh akses informasi yang dibutuhkan untuk dapat memperoleh gambaran mengenai kesesuaian pengasuhan tidak dapat diperoleh hanya melalui informasi yang terpublikasi. Oleh sebab itu penelitian ini diyakini dapat memperkaya jumlah penelitian mengenai perusahaan multibisnis di Indonesia, khususnya mengenai kesesuaian pengasuhan perusahaan induk pada perusahaan-perusahaan anak.

\section{KAJIAN PUSTAKA}

\section{Kreasi Nilai oleh Perusahaan Induk}

Perusahaan multibisnis berbeda dari perusahaan tunggal antara lain dari kemampuannya menciptakan nilai yang jauh lebih besar dari sekedar penjumlahan nilai yang diciptakan oleh unit-unit stratejik dalam kelompoknya (Basu 2010; Goold dan Campbell 2002; Landau dan Bock 2013). Nilai ini kemudian digunakan oleh perusahaan multibisnis untuk bertumbuh memperbesar skala bisnisnya.

Dengan semakin besarnya skala bisnis perusahaan, terdapat banyak manfaat yang diperoleh misalnya meningkatnya daya tawar terhadap pemasok dan distributor (Afza et al., 2008; Basu 2010) meningkatnya kemampuan mengumpulkan lebih 
banyak sumber daya (Afza et al., 2008; Ramaswamy et al., 2004). Manfaat lain adalah meningkatkan kemampuan melakukan akuisisi perusahaan lain yang nantinya akan semakin menambah skala bisnis (Chand-Olmsted dan Chang 2003; Ramaswamy et al., 2004). Selain itu, meningkatnya kemampuan untuk bertahan bila ada unit-unit bisnis yang beroperasi di industri yang tak menguntungkan (Basu 2010), dan meningkatnya kemampuan untuk bertahan menghadapi krisis lingkungan eksternal (Afza et al., 2008; Chand-Olmsted dan Chang 2003; Ramaswamy et al., 2004). Selain itu studi dari Hermann (2002) menunjukkan bahwa pertumbuhan bisnis membuat citra para eksekutif, terutama pimpinan di perusahaan multibisnis, menjadi positif di mata para pemangku kepentingan internal dan eksternal. Bertumbuhnya perusahaan multibisnis karena banyak peluang bagi para eksekutifnya untuk meningkatkan karier, kekuasaan, dan pendapatan (Collis et al., 2012; Zhou 2016). Alasan terakhir ini membuat kebanyakan perusahaan multibisnis dapat mempertahankan para eksekutifnya yang menunjukkan kinerja baik.

Pertumbuhan perusahaan multibisnis sulit dipisahkan dari peran perusahaan induk. Perusahaan induk dapat berperan sebagai investor yang mengutamakan imbal hasil setinggi-tingginya dari perusahaan-perusahaan anak, tanpa terlalu memperhatikan kemampuan perusahaan anak untuk mengelola bisnisnya (Menz et al., 2015; Munir 2010). Perusahaan induk yang berperan sebagai investor ini biasanya memiliki banyak perusahaan anak namun dengan komposisi kepemilikan yang minoritas dan relatif kecil.

Perusahaan multibisnis dengan perusahaan induk yang memiliki komposisi kepemilikan mayoritas pada perusahaan-perusahaan anaknya tentu berusaha agar perusahaan-perusahaan anak tersebut mengelola bisnisnya dengan baik. Studi terdahulu oleh Campbell et al. (1995) juga Goold dan Campbel (2002), menunjukkan bahwa perusahaan induk harus mempunyai pengaruh positif yang lebih baik dibandingkan perusahaan induk tandingan, yaitu perusahaan induk dari perusahaan multibisnis lain dengan potensi melakukan akuisisi terhadap perusahaan anak.

Perusahaan induk muncul karena kumpulan unit-unit bisnis stratejik dengan kepemilikan yang sama membutuhkan pengelolaan. Studi dari Ciabuschi et al. (2016) menunjukkan bahwa perusahaan induk berkontribusi sekitar satu hingga dua persen dari keuntungan yang dihasilkan oleh setiap unit-unit bisnis stratejik atau perusahaanperusahaan anak. Bahkan pada beberapa kasus kontribusi perusahaan induk mencapai di atas 15 persen (Aslibergi dan Rahmanseresht 2014; Menz et al. 2015; Sekulic 2009).

Kontribusi perusahaan induk pada keuntungan perusahaan anak dikenal pula sebagai kreasi nilai hasil dari keunggulan pengasuhan atau parenting advantage (Campbell et al., 1995; Goold dan Campbell 2002; Sekulic 2009). Keunggulan pengasuhan bagi perusahaan multibisnis mirip dengan keunggulan bersaing atau competitive advantage di perusahaan tunggal. Jadi perusahaan induk berperan penting dalam kreasi nilai di perusahaan multibisnis melalui pengaruhnya pada perusahaan- 
perusahaan anak. Oleh sebab itu, penting untuk diketahui apakah dalam suatu perusahaan multibisnis perusahaan induk telah berperan dalam hal kreasi nilai bagi korporasi atau kelompok bisnis secara keseluruhan.

\section{Kesesuaian Pengasuhan oleh Perusahaan Induk}

Studi terdahulu menunjukkan terdapat empat tugas perusahaan induk di perusahaan multibisnis. Pertama adalah kepemimpinan, yaitu memberikan arah stratejik yang akan menjadi panduan bagi seluruh perusahaan anak (Hermann 2002; Menz et al., 2015; Ramaswamy et al., 2004). Kedua adalah mengelola portofolio bisnis, yaitu melakukan evaluasi terhadap efektivitas portofolio dalam hal menghasilkan manfaat sebesar-besarnya bagi pemegang saham dalam jangka panjang (Menz et al., 2015; Ramaswamy et al., 2004). Ketiga adalah mengalokasikan sumber daya ke perusahaan-perusahaan anak (Basu 2010; Collis et al., 2007; Ramaswamy et al., 2004). Tugas ini sangat bergantung pada keunggulan perusahaan induk dalam menilai perusahaan-perusahaan anak mana yang akan diberi sumber daya, berapa banyak, dalam bentuk apa, dan bagaimana kontrak atau perjanjian dengan para ekskutif di tingkat perusahaan anak.

Keempat adalah tugas administrasi di internal perusahaan induk sendiri, misalnya merancang sistem administrasi, menerapkan, dan mengendalikan operasional perusahaan induk (Collis et al., 2012; Kownaski et al., 2013; Munir 2010). Studi dari Kownaski et al. (2013) menunjukkan bahwa perusahaan induk bisa kecil saja dengan jumlah karyawan di bawah 100 orang, bisa juga sangat besar dan mempekerjakan lebih dari 1000 orang untuk mengelola aspek-aspek administrasi dan pengendalian di tingkat korporat. Ukuran perusahaan induk terutama ditentukan oleh seberapa besar kegiatan fungsional seperti keuangan, sumber daya manusia, teknologi informasi, riset dan pengembangan, pemasaran dikelola langsung oleh perusahaan induk (Collis et al., 2012; Menz et al., 2015). Bila tingkat desentralisasi kegiatankegiatan fungsional ini besar, ukuran perusahaan induk tidak besar. Kreasi nilai bisa dilaksanakan oleh perusahaan induk bila keempat tugas di atas bisa dikelola dengan baik.

Pengelolaan oleh perusahaan induk dipengaruhi oleh karakteristik perusahaan induk. Dalam hal kepemimpinan misalnya dipengaruhi oleh karakteristik direktur utama atau CEO (Hermann 2002), latar belakang dan gaya kepemimpinan para ekskutif di perusahaan induk (Rasmawamy et al., 2004), budaya organisasi (ChanOlmsted dan Chang 2003), dan pengalaman masa lalu perusahaan multibisnis (Menz et al., 2015). Selain para pimpinan tertinggi, kompetensi dan latar belakang sumber daya manusia di perusahaan induk juga mempengaruhi kualitas tugas pengelolaan administratif (Goold dan Campbell 2002). Struktur, sistem, dan proses yang ada di perusahaan induk mempengaruhi efektivitas peran perusahaan induk dalam memberikan arah stratejik, pengelolaan portofolio, dan alokasi sumber daya (Collis et al., 2012; Kownaski et al., 2013). 
Goold dan Campbell (2002) menyampaikan ada tiga gaya pengasuhan perusahaan induk terhadap perusahaan anak. Pertama adalah strategic planning dimana perusahaan induk bekerja bersama perusahaan-perusahaan anak untuk merumuskan sasaran ke depan, strategi pencapaian, serta ukuran-ukuran keberhasilannya. Kedua adalah strategic control dimana tanggung jawab perumusan sasaran, strategi, impelementasi, dan pengembangan ukuran keberhasilan berada di tangan perusahaan anak. Pada gaya kedua ini, perusahaan induk berperan dalam memberikan tema stratejik ke depan yang menjadi inspirasi bagi perusahaanperusahaan anak. Studi dari Basu (2010) menunjukkan bahwa gaya ini umumnya diterapkan pada perusahaan multibisnis yang melakukan diversifikasi berhubungan (related diversification).

Ketiga adalah financial control, dimana perusahaan induk menyerahkan seluruhnya tugas dan tanggung jawab stratejik dan operasional pada perusahaan anak. Bahkan perusahaan induk dengan prinsip pengasuhan dengan pengendalian keuangan ini memperlakukan masing-masing perusahaan anak sebagai bisnis tunggal dan tidak berusaha membangun sinergi di antara perusahaan anak (Landau dan Bock 2013; Martin dan Eisenhardt 2010).

Memperhatikan peran penting perusahaan induk dalam kreasi nilai, studi terdahulu menunjukkan bahwa perusahaan induk dapat melakukan kreasi nilai bila karakteristik perusahaan induk sesuai dengan kebutuhan perusahaan anak (Campbell et al., 1995; Goold dan Campbell 2002). Dengan kata lain, ada peluang pengasuhan yang bisa dimanfaat oleh perusahaan induk terhadap perusahaan anak.

Kreasi nilai juga bisa terjadi bila perusahaan induk cukup memahami bisnis perusahaan-perusahaan anak. Seperti disampaikan oleh Swaminathan et al. (2008) untuk memahami bisnis perusahaan anak, perusahaan induk perlu memahami faktorfaktor sukses yang dipandang kritis dalam mengelola bisnis di industri dimana perusahaan anak beroperasi.

Campbell et al. (1995) serta Goold dan Campbell (2002) mengembangkan sebuah matriks yang dapat memetakan kesesuaian pengasuhan antara perusahaan induk dan perusahaan anak. Matriks yang disebut sebagai matriks kesesuaian pengasuhan (parenting fit matrix) ini memetakan perusahaan anak ke dalam empat kuadran seperti pada Gambar 1. Kuadran pertama adalah heartland dan edge of heartland dimana terdapat banyak kesesuaian antara karakteristik perusahaan induk, faktor sukses kritis perusahaan anak, dan peluang-peluang pengasuhan yang ada. Menurut Goold dan Campbell (2002) perbedaan antara perusahaan-perusahaan anak yang terletak di kuadran heartland dengan yang terletak di edge of heartland hanya pada perbedaan relatif jumlah kesesuaian antara karakteristik perusahaan induk, faktor sukses kritis perusahaan anak, dan peluang-peluang pengasuhan yang ada. Kedua adalah ballast dimana perusahaan induk memahami bisnis perusahaan anak namun sedikit peluang pengasuhan untuk menciptakan nilai pada perusahaan-perusahaan 
anak ini. Ketiga adalah value trap dimana banyak peluang pengasuhan di perusahaanperusahaan anak yang bisa dimanfaatkan oleh perusahaan induk, sayangnya perusahaan induk tidak memiliki kompetensi dan/atau sumber daya yang sesuai. Terakhir adalah alien territory dimana sedikit sekali atau bahkan tidak ada kesesuaian antara karakteristik perusahaan induk, faktor sukses kritis, dan peluang pengasuhan yang ada.

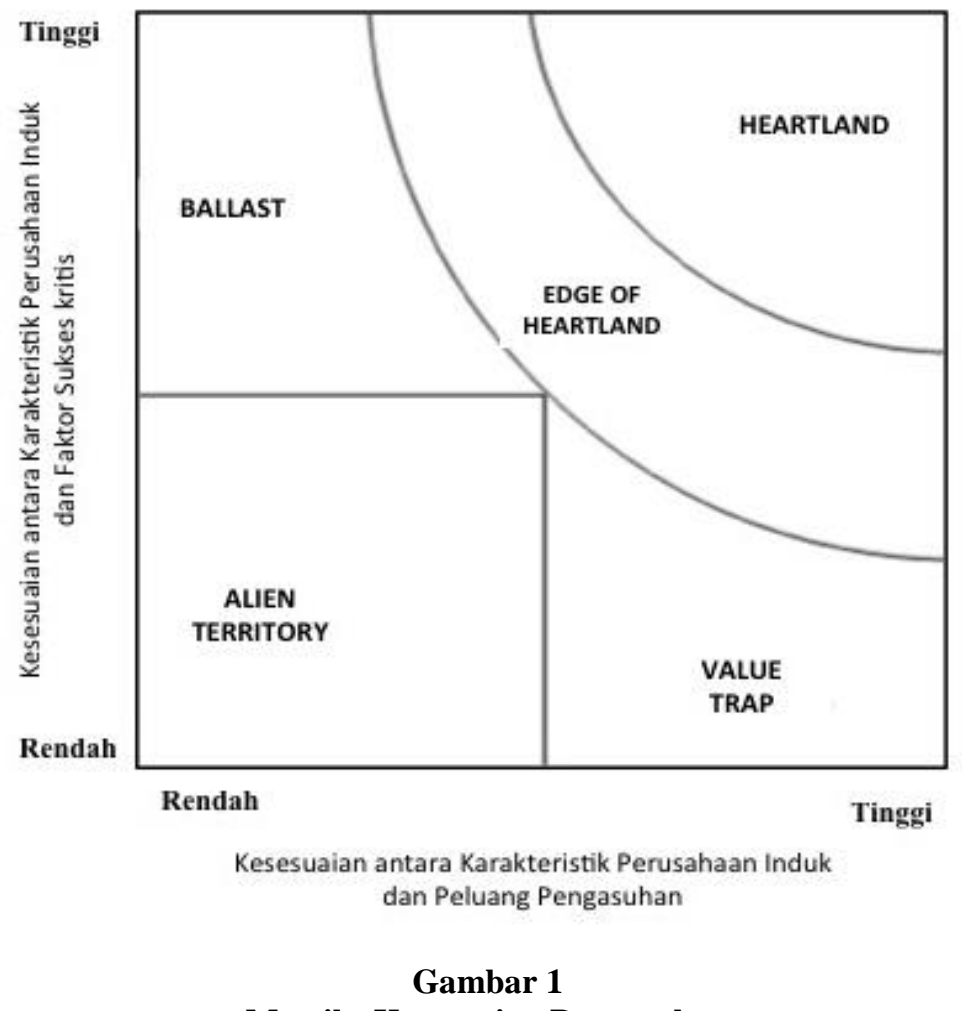

Matriks Kesesuaian Pengasuhan

Seperti telah disampaikan sebelumnya, dalam suatu perusahaan multibisnis, perusahaan induk berperan penting dalam kreasi nilai yang akan membuat korporasi dapat bertumbuh. Untuk mengetahui apakah kreasi nilai memang terjadi, perlu diteliti lebih lanjut bagaimana karakteristik perusahaan induk, faktor sukses kritis perusahaan anak, dan peluang-peluang pengasuhan yang ada. Lebih lanjut, penggunaan matriks kesesuaian pengasuhan seperti yang digagas oleh Campbell et al. (1995) diharapkan dapat memudahkan analisis yang melibatkan banyak entitas perusahaan yang tergabung dalam sebuah kelompok bisnis.

\section{METODA PENELITIAN}

Untuk mencapai tujuan penelitian dilakukan identifikasi atas karakteristik perusahaan induk, faktor-faktor sukses kritis perusahaan-perusahaan anak, dan peluang-peluang pengasuhan yang ada saat ini. Pendekatan penelitian kualitatif dipilih karena dengannya peneliti akan dapat memperoleh pemahaman mendalam mengenai 
fenomena tertentu yang menjadi fokus penelitian (Baxter dan Jack, 2008; Gummeson 2006). Fenomena yang menjadi daya tarik dalam penelitian ini adalah kesesuaian pengasuhan di perusahaan multibisnis.

Metode studi kasus dipilih karena metode ini memungkinkan peneliti melakukan ekplorasi dan pemaknaan isu-isu kompleks (Bennet dan Elman 2006; Baxter dan Jack, 2008). Salah satu alasan kuat untuk memilih studi kasus sebagai metoda penelitian adalah keterbatasan metoda kuantitatif dalam memberikan penjelasan holistik dan mendalam tentang fenomena yang diteliti. Melalui metoda studi kasus, peneliti mampu melampaui hasil statistik kuantitatif dan memahami kondisi perilaku melalui perspektif para aktor pelaku (Gummeson 2006).

Yin (2003) menyampaikan bahwa terdapat tiga kategori studi kasus: eksploratori, deskriptif, dan eksplanasi. Pada studi kasus kategori eksploratori, penelitian menjawab pertanyaan, "Apakah MG menerapkan strategi pengasuhan?". Pertanyaan ini telah dijawab melalui pernyataan perusahaan dalam Laporan Tahunan 2012 yang menyampaikan bahwa perusahaan induk mengelola perusahaan-perusahaan anak melalui seperangkat kebijakan dan keputusan mengenai alokasi sumber daya dan aksi stratejik korporat.

Pada studi kasus kategori deskriptif, penelitian menjawab pertanyaan, "Bagaimana strategi pengasuhan korporat diterapkan di MG?". Tantangan yang dihadapi peneliti yang menggunakan studi kasus deskriptif adalah memulai penelitian dengan teori yang mendukung deskripsi fenomena tertentu, dalam hal ini penerapan strategi pengasuhan korporat. Pada studi kasus kategori eksplanatif, penelitian dilakukan untuk memperoleh pemahaman mendalam mengenai fenomena yang ada. Penelitian dilakukan untuk menjawab pertanyaan, "Mengapa MG menerapkan strategi pengasuhan korporat tertentu?". Berdasarkan temuan dari data atau informasi yang telah dianalisis mendalam, peneliti kemudian mengembangkan suatu teori dan menguji teori tersebut, misalnya dengan pendekatan kuantitatif. Berdasarkan uraian di atas, penelitian ini menggunakan metoda studi kasus deskriptif.

Dalam mendefinisikan kasus yang akan diteliti, Stake (1995) membedakan tiga jenis kasus: intrinsik, intrumental dan kolektif. Pada studi kasus intrinsik, peneliti melakukan investigasi untuk kepentingannya sendiri. Pada studi kasus instrumental, peneliti memiliki sebuah kelompok untuk melakukan eksplorasi mendalam mengenai fenomena tertentu, misalnya perilaku individu, kelompok, atau organisasi. Sedangkan pada studi kasus kolektif, peneliti mengelola data yang diperoleh dari berbagai sumber, melakukan pengelompokan data dan menganalisisnya untuk memperoleh suatu pemahaman. Sesuai dengan tujuannya, penelitian ini menggunakan metoda studi kasus dengan jenis kolektif.

Penelitian ini dilakukan pada perusahaan multibisnis Media Group (MG) yang memiliki bisnis inti di bidang media. Pada awalnya MG hanya terdiri dari satu perusahaan yang mengelola sebuah stasiun televisi swasta di Jakarta. Dalam Laporan 
Tahunan tahun 2015 MG mempunyai satu perusahaan yang berperan sebagai perusahaan induk dan 15 perusahaan anak. Beberapa perusahaan anak juga menjadi induk bagi perusahaan-perusahaan "cucu" yang kebanyakan merupakan perusahaan media lokal. Perusahaan induk MG adalah perusahaan publik, demikian pula empat dari 15 perusahaan anak dalam koordinasinya. Tabel 1 menunjukkan bisnis inti masing-masing perusahaan anak. Dalam penelitian ini, "No Kode Perusahaan" selanjutnya akan digunakan secara konsisten untuk merujuk pada entitas perusahaan anak.

Tabel 1

Bisnis Inti Perusahaan Anak dan Jumlah Narasumber Wawancara

\begin{tabular}{cll}
\hline \multirow{2}{*}{ No Kode Perusahaan } & \multicolumn{1}{c}{ Bisnis Inti } & \multicolumn{1}{c}{$\begin{array}{c}\text { Jumlah \& Jabatan } \\
\text { Narasumber }\end{array}$} \\
\hline Induk & Investasi & 3 direktur \\
& & 1 sekretaris perusahaan \\
1 & Penyiaran Televisi & 2 direktur \\
2 & Penyiaran Televisi & 2 direktur \\
3 & Penyiaran Televisi & 2 direktur \\
4 & Penyiaran Televisi & 2 direktur \\
5 & Stasiun Radio & 2 direktur \\
6 & Media Cetak & 2 direktur \\
7 & Media Cetak & 2 direktur \\
8 & Media Cetak & 2 direktur \\
9 & Media Online & 1 direktur \\
10 & Agensi Periklanan & 2 direktur \\
11 & Agensi Periklanan & 2 direktur \\
12 & Manajemen Bakat & 2 direktur \\
13 & Rumah Produksi & 2 direktur \\
14 & Lisensi & 1 direktur \\
15 & Investasi & 1 direktur \\
\hline
\end{tabular}

Data primer diperoleh terutama melalui wawancara dengan para anggota direksi, baik diperusahaan induk maupun perusahaan-perusahaan anak, juga dengan sekretaris perusahaan MG. Protokol wawancara dikembangkan dari hasil studi terdahulu yang dilakukan oleh Aslibergi dan Rahmanseresht (2014); Campbell et al. (1995); Collis et al. (2012); Hermann (2002); dan Kruehler et al. (2012). Protokol observasi dikembangkan dari hasil studi oleh Kruehler et al. (2012). Kinerja perusahaan anak dilihat dari tiga hal, yaitu pertumbuhan pendapatan, laba operasi, dan Return on Asset (ROA). Seluruh indikator kinerja dilihat dari tiga tahun berturut-turun yaitu 2013, 2014, dan 2015.

Direktur utama MG juga merupakan pemilik dan karena kesibukannya hanya dapat diwawacara secara tertulis, dilengkapi dengan satu kali wawancara pendalaman selama dua jam. Wawancara dengan anggota dewan direksi perusahaan induk dan perusahaan-perusahaan anak dilakukan dua kali selama kurang lebih dua jam. Sebelum wawancara tatap muka dilaksanakan, daftar pertanyaan dikirimkan pada seluruh narasumber. Transkrip hasil wawancara kemudian diperiksa oleh sekretaris perusahaan terutama untuk ketepatan data internal perusahaan. Tabel 1 sebelumnya 
juga menunjukkan bisnis inti masing-masing perusahaan anak, jumlah dan asal perusahaan anggota dewan direksi yang diwawancara.

Peneliti juga mendapat peluang dua kali observasi, yaitu saat mengikuti rapat antara direktur utama dengan direksi seluruh perusahaan anak. Hasil wawancara dan observasi kemudian diproses dengan menggunakan perangkat pengolah data kualitatif Atlas.ti 7 untuk mengidentifikasi kata-kata kunci yang dikelompokkan dalam faktor karakteristik perusahaan induk, faktor-faktor sukses kritis perusahaan-perusahaan anak, dan peluang pengasuhan. Hasil pengelompokkan kata-kata kunci kemudian dikembalikan ke seluruh nara sumber direksi perusahaan induk dan perusahaanperusahaan anak, serta sekretaris perusahaan untuk memperoleh komentar dan meningkatkan akurasi.

Selain wawancara, data primer juga diperoleh melalui kuesioner sederhana yang dikirimkan pada anggota dewan direksi dan para eksekutif setingkat di bawah direktur perusahaan anak (general manager dan vice president). Tujuan penyebaran kuesioner adalah untuk memperoleh persepsi narasumber mengenai kesesuaian antara karakteristik perusahaan induk dengan faktor-faktor sukses kritis perusahaanperusahaan anak, serta kesesuaian antara karakteristik perusahaan induk dengan peluang pengasuhan. Persepsi narasumber tersebut diukur dengan skala likert yang terdiri dari: (1) Sangat tidak sesuai, (2) Tidak sesuai, (3) Rata-rata, (4) Sesuai, dan (5) Sangat sesuai.

Data sekunder diperoleh melalui studi dokumen. Ada dua macam dokumen yang dipelajari dalam penelitian ini. Pertama dokumen dari perusahaan dalam bentuk laporan tahunan tahun 2012 hingga 2015 serta company profile MG serta company profile empat perusahaan anak. Selain dokumen tertulis, data sekunder juga diperoleh melalui situs resmi perusahaan-perusahaan anak. Jenis dokumen kedua adalah hasil liputan media masa mengenai aksi korporat MG dan perusahaan-perusahaan anaknya. Media yang dianalisis dibatasi hanya media nasional yaitu: Majalah Berita Mingguan TEMPO dan kelompoknya seperti Koran Tempo dan portal berita tempo.co (http://www.tempo.co/), majalah bisnis SWA dan portal beritanya SWA.co.id (http://swa.co.id/), harian KOMPAS dan kelompoknya seperti KOMPAS.com (http://www.kompas.com/) dan Jakarta Post, portal berita SindoNews (http://www.sindonews.com/), dan portal berita okezone (http://www.okezone.com/).

Untuk menjaga kualitas penelitian, dilakukan triangulasi data dan teori (Bennet dan Elman 2006). Pertama dilakukan triangulasi data dimana data yang diperoleh kemudian disajikan kepada nara sumber berbeda (cross-check), disampaikan pada sekretaris perusahaan untuk memeriksa ketepatan data dan kepatuhan pada aspek legal kerahasiaan perusahaan, serta dibandingkan dengan data dan informasi dari sumbersumber eksternal. Hasil wawancara dan observasi dibandingkan untuk melihat apakah hasil temuan sama. Selanjutnya dilakukan pula triangulasi teori untuk memaknakan 
data yang teah dikumpulkan dan diolah. Penggunaan berbagai perspektif untuk menafsirkan data yang diperoleh akan meningkatkan kualitas hasil penelitian ini.

\section{ANALISIS DAN PEMBAHASAN}

\section{Karakteristik Perusahaan Induk}

Dari Laporan Tahunan 2015, diketahui bahwa cikal bakal MG adalah sebuah stasiun televisi free-to-air (FTA) yang berdiri tahun 1987. Perusahaan induk sendiri dibentuk pada tahun 2012 saat melepas saham ke publik. Pada tahun 2015 MG membukukan pendapatan sebesar Rp6,44 triliun dan laba bersih Rp1,185 triliun. Pendapatan MG disumbang sekitar 90 persennya dari iklan di perusahaan-perusahaan anak yang bergerak di bidang stasiun televisi FTA. Besar aset yang dikuasai oleh MG adalah Rp14 triliun yang terdiri dari 22 stasiun TV, perpustakaan konten sebesar 270.000 jam, dan fasilitas pusat studio yang terdiri dari 28 studio. Dalam tiga tahun, aset korporasi terus meningkat. Sementara pendapatan dan laba operasi pada tahun 2014 mengalami penurunan sebesar 8 persen dan 11 persen dari tahun 2013, namun kembali meningkat di tahun 2015.

Pada tahun 2015 di perusahaan induk terdapat delapan orang anggota dewan direksi, dengan pemilik menduduki posisi sebagai direktur utama. Direktur utama merupakan sosok yang sangat dominan, tidak saja dalam hal pengambilan keputusan mengenai arah stratejik korporat, juga dalam hal menetapkan, dan menerapkan visi perusahaan. Beliau merupakan pendiri dan pemilik MG yang dipandang oleh para direksi (di perusahaan induk maupun perusahaan anak) sebagai sosok yang visioner. Selain itu direktur utama juga dipandang sebagai sosok yang sangat ahli di bidang keuangan. Selain menetapkan arah stratejik dan pilar pertumbuhan korporasi, di bawah kepemimpinan direktur utama perusahaan induk juga menetapkan perencanaan keuangan, pengawasan keuangan dan manajemen keuangan di seluruh perusahaan anak. Setiap dua minggu secara bergantian direksi perusahaan anak bertemu dengan direktur utama korporasi atau salah satu direktur di tingkat korporat. Setahun dua kali, dilaksanakan pertemuan antara seluruh direksi perusahaan anak dengan direktur utama.

Direktur utama yang memiliki pengalaman panjang dalam bidang media juga menduduki posisi sebagai direktur utama di salah satu perusahaan anak - stasiun TV FTA - yang memiliki kontribusi pendapatan terbesar. Seperti direktur utama, empat direktur lainnya juga memiliki pengalaman panjang dan keahlian di industri media. Masing-masing membawahkan bisnis stasiun TV FTA, bisnis media cetak, bisnis konten, dan pengembangan produk serta portofolio bisnis media. Keempat direktur ini juga menjabat sebagai direktur utama perusahaan-perusahaan anak yang berbeda dan telah bergabung dalam MG lebih dari satu dekade. 
Tiga direktur lainnya sesuai dengan pengalaman dan keahliannya membawahkan masing-masing bidang keuangan, bidang sumber daya manusia, dan teknologi. Seluruh direktur ini menyusun kebijakan, strategi dan asumsi yang menjadi acuan bagi seluruh perusahaan anak. Wawancara dengan direksi di perusahaan induk dan direksi di perusahaan-perusahaan anak menunjukkan bahwa beberapa aspek fungsional membutuhkan koordinasi dengan direksi terkait di perusahan induk. Misalnya untuk aspek sumber daya manusia, penetapan dan perubahan struktur dewan direksi di perusahaan anak seluruhnya merupakan otoritas perusahaan induk. Promosi, mutasi dan rotasi eksekutif di tingkat vice president dan general manager dalam satu entitas perusahaan anak maupun lintas perusahaan anak juga harus didiskusikan dan disetujui oleh perusahaan induk. Demikian pula investasi teknologi dan pengembangan cetak biru teknologi informasi seluruhnya dikendalikan oleh perusahaan induk.

Untuk fungsi keuangan hampir seluruhnya dipegang oleh perusahaan induk. Di tingkat perusahaan anak, hanya ada dua perusahaan anak yang mempunyai direktur keuangan. Direksi di perusahaan anak menyampaikan bahwa tugas dan tanggung jawab di tingkat perusahaan anak adalah dalam hal pengembangan produk dan konten yang berkualitas serta menjual. Dari wawancara dengan direktur utama dan direktur di perusahaan induk diketahui bahwa perusahaan induk juga mengendalikan pengembangan portofolio bisnis dan sinergi antar perusahaan anak. Dari 15 perusahaan anak dan entitas "cucu," hanya dua perusahaan anak yang dikembangkan secara organik. Perusahaan-perusahaan anak lainnya dikembangkan melalui akuisisi.

Tabel 2

Karakteristik Perusahaan Induk

\begin{tabular}{|c|c|}
\hline Peringkat & Karakteristik \\
\hline 1 & $\begin{array}{l}\text { Memiliki pengalaman dan keahlian dalam mengelola bisnis media, khususnya } \\
\text { pengembangan konten dan jaringan stasiun televisi FTA }\end{array}$ \\
\hline 2 & Memiliki sosok direktur utama yang visioner dan dihormati \\
\hline 3 & Memiliki akses pada sumber daya keuangan/investor \\
\hline 4 & Memiliki keahlian dalam pengelolaan portofolio bisnis dan keuangan \\
\hline 5 & $\begin{array}{l}\text { Memiliki keahlian dan disiplin dalam hal perencanaan, pengawasan, dan manajemen } \\
\text { keuangan }\end{array}$ \\
\hline 6 & $\begin{array}{l}\text { Memiliki keahlian dalam bidang pengembangan sumber daya manusia, khususnya di } \\
\text { industri media }\end{array}$ \\
\hline
\end{tabular}

Sesudah penjelasannya, yang dimulai dengan pengolahan hasil wawancara dan informasi dari dokumen tertulis kemudian diolah dengan perangkat Atlas.ti 7 untuk mengindentifikasikan karakteristik perusahaan induk. Karakteristik induk yang teridentifikasi kemudian didistribusikan ke seluruh narasumber untuk disepakati definisi dan peringkatnya. Tabel 2 menunjukkan enam karakteristik unit perusahaan induk.

\section{Faktor-faktor Sukses Kritis}


Menurut wawancara dengan direktur utama, yang didukung oleh penjelasan dalam Annual Report 2015, dalam dunia media ada empat hal yang penting, yang disebutnya sebagai CARR, yaitu Content, Awareness, Reach, dan Reception. Content (C) meliputi isi program, kualitas program, jumlah program dan variasi program. Awareness (A) meliputi segala sesuatu yang berkaitan dengan promosi, brand, citra perusahaan, program atau produk yang harus dikenal baik oleh konsumen. Reach (R1) atau jangkauan meliputi jumlah stasiun pemancar yang dimiliki MG, misalnya stasiun televisi ditonton oleh pemirsa Indonesia, sampai dengan bagian Indonesia mana saja yang bisa dijangkau oleh siaran dari stasiun televisi milik MG. Bila dikaitkan dengan TV berjaringan, maka reach akan berkaitan dengan banyaknya stasiun TV daerah yang dimiliki untuk menunjang penyebaran siaran. Terakhir adalah reception (R2) yang meliputi kualitas siaran yang ditayangkan, yaitu apakah gambarnya jernih, suaranya bagus, segala hal yang berkaitan dengan teknis tayangan. Dari dua kali peluang melakukan observasi dalam rapat direksi di MG, faktor CARR secara konsisten terus ditekankan oleh direktur utama. Direktur utama juga mengaskan bahwa MG akan terus berkembang, namun hanya ke industri-industri yang dipandang mendukung bisnis intinya. Selain oleh direktur utama, wawancara dengan para direksi juga menunjukkan bahwa faktor CARR juga menjadi faktor-faktor yang merekat dan menjaga keberhasilan seluruh perusahaan anak.

Komponen faktor sukses kritis di atas kemudian disampaikan pada para direksi perusahaan-perusahaan anak. Sesuai dengan bisnis inti perusahaannya, masing-masing nara sumber direksi kemudian memberikan tingkat kepentingan masing-masing faktor sukses kritis. Pada beberapa perusahaan anak, nara sumber memberi penjelasan bila komponen CARR dipandang tidak relevan di industrinya, dan/atau menambahkan beberapa faktor sukses kritis yang dipandang sangat relevan dengan bisnis intinya.

Faktor sukses kritis lain yang dipandang relevan bagi beberapa perusahaan anak adalah ketersediaan sumber daya manusia yang ahli di bidangnya (S). Hal ini dipandang penting karena bisnis media membutuhkan sumber daya manusia dengan kompetensi yang spesifik. Perusahaan anak dengan bisnis inti stasiun radio, manajemen bakat, dan rumah produksi menambahkan star talent ( $\mathrm{T}$ ) atau sosok pesohor yang disukai konsumen sebagai faktor kritis yang menentukan keberhasilan bisnisnya. Sementara perusahaan anak yang memproduksi berita menegaskan bahwa akses pada pemerintah (P) merupakan salah satu faktor kritis dalam industrinya. Tabel 3 menunjukkan faktor-faktor sukses kritis masing-masing perusahaan anak serta tingkat kepentingannya.

Tabel 3

Faktor Sukses Kritis Perusahaan Anak

\begin{tabular}{ccccccccc}
\hline No Kode & \multirow{3}{*}{ Bisnis Inti } & \multicolumn{5}{c}{ Faktor Sukses Kritis* } \\
\cline { 3 - 7 } Perusahaan & C & A & R1 & R2 & S & T & P \\
\hline
\end{tabular}




\begin{tabular}{|c|c|c|c|c|c|c|c|c|}
\hline 1 & Penyiaran Televisi & $\mathbf{t}$ & $\mathbf{t}$ & $\mathbf{t}$ & $\mathbf{t}$ & $\mathbf{t}$ & & $\mathbf{S}$ \\
\hline 2 & Penyiaran Televisi & $\mathbf{t}$ & $\mathbf{t}$ & $\mathbf{t}$ & $\mathbf{t}$ & $\mathbf{t}$ & & $\mathbf{s}$ \\
\hline 3 & Penyiaran Televisi & $\mathbf{t}$ & $\mathbf{t}$ & $\mathbf{t}$ & $\mathbf{t}$ & $\mathbf{t}$ & & $\mathbf{t}$ \\
\hline 4 & Penyiaran Televisi & $\mathbf{t}$ & $\mathbf{t}$ & $\mathbf{t}$ & $\mathbf{t}$ & $\mathbf{t}$ & & $\mathbf{s}$ \\
\hline 5 & Stasiun Radio & $\mathbf{t}$ & $\mathbf{t}$ & $\mathbf{t}$ & $\mathbf{t}$ & $\mathbf{t}$ & $\mathbf{S}$ & $\mathbf{s}$ \\
\hline 6 & Media Cetak & $\mathbf{t}$ & $\mathbf{t}$ & $\mathbf{t}$ & $\mathbf{t}$ & $\mathbf{t}$ & & $\mathbf{t}$ \\
\hline 7 & Media Cetak & $\mathbf{t}$ & $\mathbf{t}$ & $\mathbf{t}$ & $\mathbf{t}$ & $\mathbf{t}$ & & \\
\hline 8 & Media Cetak & $\mathbf{t}$ & $\mathbf{t}$ & $\mathbf{t}$ & $\mathbf{t}$ & $\mathbf{t}$ & & \\
\hline 9 & Media Online & $\mathbf{t}$ & $\mathbf{t}$ & $\mathbf{t}$ & $\mathbf{t}$ & $\mathbf{t}$ & & $\mathbf{t}$ \\
\hline 10 & Agensi Periklanan & $\mathbf{t}$ & $\mathbf{t}$ & $\mathbf{t}$ & $\mathbf{t}$ & $\mathbf{t}$ & & $\mathbf{S}$ \\
\hline 11 & Agensi Periklanan & $\mathbf{t}$ & $\mathbf{t}$ & $\mathbf{t}$ & $\mathbf{t}$ & $\mathbf{t}$ & & $\mathbf{S}$ \\
\hline 12 & Manajemen Bakat & $\mathbf{r}$ & $\mathbf{t}$ & $\mathbf{r}$ & & $\mathbf{t}$ & $\mathbf{t}$ & \\
\hline 13 & Rumah Produksi & $\mathbf{t}$ & $\mathbf{t}$ & $\mathbf{r}$ & & $\mathbf{t}$ & $\mathbf{t}$ & \\
\hline 14 & Lisensi & $\mathbf{t}$ & $\mathbf{t}$ & $\mathbf{r}$ & & $\mathbf{s}$ & & $\mathbf{S}$ \\
\hline 15 & Investasi & $\mathbf{S}$ & $\mathbf{r}$ & & & $\mathbf{t}$ & & $\mathbf{t}$ \\
\hline
\end{tabular}

*Keterangan Faktor Sukses Kritis dan penilaiannya:

$\mathrm{t}=$ tinggi dampaknya; $\mathrm{s}=$ sedang dampaknya; $\mathrm{r}=$ rendah dampaknya.

\section{Peluang Pengasuhan}

Peluang pengasuhan adalah kondisi dimana perusahaan-perusahaan anak membutuhkan bantuan dari perusahaan induk agar dapat menciptakan nilai (Aslibergi dan Rahmanseresht 2014; Campbell et al. 1995; Goold dan Campbell 2002). Dari hasil wawancara dengan direksi perusahaan anak, ditemukan ada lima peluang pengasuhan.

Pertama adalah arah stratejik (S; Stratejik) yaitu keputusan dari perusahaan induk mengenai pertumbuhan portofolio bisnis. Narasumber menyampaikan bahwa untuk menjalankan bisnisnya, perusahaan-perusahaan anak membutuhkan keputusan mengenai besarnya pertumbuhan bisnis dan komposisinya. Narasumber menyampaikan bahwa direktur utama menegaskan adanya "lima pilar pertumbuhan" yang menjadi sumber dan penyokong pertumbuhan bisnis secara keseluruhan. Dengan adanya arahan tersebut masing-masing perusahaan anak selain dapat mengetahui posisinya di antara portofolio bisnis MG juga mengetahui langkah stratejik apa yang harus dilakukan ke depan.

Kedua adalah dukungan pendanaan atau investasi (D; Dana) yaitu dukungan dana terkait investasi yang harus dilakukan perusahaan anak untuk mendukung penerapan strategi bisnisnya. Narasumber juga menyampaikan bahwa dana tidak harus datang internal MG, melainkan dapat berasal dari pihak di luar MG. Upaya pendanaan dilakukan sepenuhnya oleh perusahaan induk.

Ketiga adalah dukungan pengelolaan sumber daya manusia $(\mathrm{H}$; Human Capital) yaitu memastikan bahwa di setiap perusahaan anak tersedia sumber daya manusia dengan jumlah dan kompetensi sesuai dengan kebutuhan. Hal ini terkait erat dengan faktor sukses kritis yang telah disampaikan sebelumnya. Industri media membutuhkan sumber daya manusia dengan kompetensi yang spesifik. Dengan terus bertumbuhnya bisnis, maka meningkat pula kebutuhan sumber daya manusianya. Selain itu, baik direksi di perusahaan induk maupun perusahaan anak menyampaikan perlunya ada rotasi sumber daya manusia, baik karyawan kunci maupun karyawan 
pada umumnya, di antara perusahaan-perusahaan anak. Perusahaan induk juga mempunyai otoritas melakukan promosi dan mutasi eksekutif di dalam perusahaan anak dan antar perusahaan anak.

Keempat adalah keterkaitan antar unit bisnis stratejik (K; Keterkaitan) yaitu koordinasi dan sinergi antar perusahaan anak. Hal ini adalah untuk memastikan keselarasan jadual rapat pimpinan internal perusahaan anak dengan rapat pimpinan antar perusahaan dalam industri sejenis atau antar industri. Hal yang dipandang penting oleh ara narasumber adalah sinergi dalam penayangan program. Perlu dipastikan ada koordinasi antara star talent, program di stasiun TV yang satau dengan yang lain, program di radio, dan liputan di media cetak, dengan demikian dampak ke pasar menjadi semaksimal mungkin. Dari direksi di perusahaan induk, koordinasi dan sinergi antar perusahaan-perusahaan anak sangat penting karena korporasi atau MG dapat menjual program pada pelanggan perusahaan secara bundling (paket). Selain memberi dampak optimal bagi pelanggan perusahaan, juga memberikan pendapatan bagi banyak anak perusahaan sekaligus.

Terakhir adalah akses pada jejaring berkualitas (A; Akses) yaitu kebutuhan perusahaan-perusahaan anak untuk memiliki akses yang memberi dampak positif bagi bisnisnya. Misalnya pihak pemerintah baik pusat maupun daerah, investor dalam dan luar negeri, perusahaan sejenis di luar negeri, dan sebagainya. Narasumber menyampaikan bahwa dengan berhadapan sebagai kelompok bisnis, keinginan atau kepentingan perusahaan-perusahan anak akan lebih mudah tersampaikan oleh perusahaan induk. Juga karena skala bisnisnya, keinginan atau kepentingan ini seringkali mendapat respons yang positif dari pihak eksternal tersebut.

Tabel 4 memuat relevansi antara peluang pengasuhan dengan perusahaanperusahaan anak. Tidak semua peluang pengasuhan ada di setiap perusahaan anak. Perusahaan anak dengan bisnis inti investasi dan lisensi pada saat wawancara merasa bahwa saat penelitian dilakukan tidak ada kebutuhan mengenai sumber daya manusia yang berkualitas. Nara sumber menyampaikan bahwa saat ini perusahaannya memiliki cukup orang dengan kompetensi yang baik sekali.

Tabel 4

Peluang Pengasuhan

\begin{tabular}{clllllll}
\hline Kode & \multirow{3}{*}{ Bisnis Inti } & \multicolumn{4}{c}{ Peluang Pengasuhan* } \\
\cline { 3 - 7 } Perusahaan & & S & D & H & K & A \\
\hline 1 & Penyiaran Televisi & $\checkmark$ & $\checkmark$ & $\checkmark$ & $\checkmark$ & $\checkmark$ \\
2 & Penyiaran Televisi & $\checkmark$ & $\checkmark$ & $\checkmark$ & $\checkmark$ & $\checkmark$ \\
3 & Penyiaran Televisi & $\checkmark$ & $\checkmark$ & $\checkmark$ & $\checkmark$ & $\checkmark$ \\
4 & Penyiaran Televisi & $\checkmark$ & $\checkmark$ & $\checkmark$ & $\checkmark$ & $\checkmark$ \\
5 & Stasiun Radio & & $\checkmark$ & $\checkmark$ & $\checkmark$ & $\checkmark$ \\
6 & Media Cetak & & $\checkmark$ & $\checkmark$ & $\checkmark$ & $\checkmark$ & $\checkmark$ \\
\hline
\end{tabular}




\begin{tabular}{cllllll}
\hline 7 & Media Cetak & $\checkmark$ & $\checkmark$ & $\checkmark$ & $\checkmark$ & $\checkmark$ \\
8 & Media Cetak & $\checkmark$ & $\checkmark$ & $\checkmark$ & $\checkmark$ & $\checkmark$ \\
9 & Media Online & $\checkmark$ & $\checkmark$ & $\checkmark$ & $\checkmark$ & $\checkmark$ \\
10 & Agensi Periklanan & $\checkmark$ & $\checkmark$ & $\checkmark$ & $\checkmark$ & $\checkmark$ \\
11 & Agensi Periklanan & $\checkmark$ & $\checkmark$ & $\checkmark$ & $\checkmark$ & $\checkmark$ \\
12 & Manajemen Bakat & $\checkmark$ & $\checkmark$ & $\checkmark$ & $\checkmark$ & $\checkmark$ \\
13 & Rumah Produksi & $\checkmark$ & $\checkmark$ & $\checkmark$ & $\checkmark$ & $\checkmark$ \\
14 & Lisensi & $\checkmark$ & $\checkmark$ & & $\checkmark$ & $\checkmark$ \\
15 & Investasi & $\checkmark$ & $\checkmark$ & & $\checkmark$ & $\checkmark$ \\
\hline
\end{tabular}

* Keterangan Peluang Pengasuhan:

$\checkmark=$ Relevan

\section{Kesesuaian Pengasuhan}

Sebanyak 150 kuesioner disampaikan pada direksi di perusahaan induk, direksi di perusahaan anak dan para eksekutif satu tingkat di bawah direksi (General Manager dan Vice President). Kuesioner bertujuan untuk menangkap pendapat responden mengenai dua hal, yaitu (1) kesesuaian antara karakteristik pengasuhan dengan faktor sukses kritis, dan (2) kesesuaian antara karakteristik pengasuhan dengan peluang pengasuhan. Jumlah kuesioner yang kembali adalah 67 kuesioner, dan 62 di antaranya dapat diolah datanya atau sekitar 41,33 persen. Hasil pengolahan kemudian dipetakan dalam sebuah matriks yang dikenal sebagai matriks kesesuaian pengasuhan seperti pada Gambar 2. Sesuai dengan studi terdahulu dari Kruehler et al. (2012), baik sumbu $\mathrm{X}$ maupun sumbu Y menggunakan pernyataan positif: "kesesuaian (fit); bukan "ketidaksesuaian" (misfit).

Hasil pemetaan menunjukkan bahwa seluruh 15 perusahaan anak MG terletak di kuadran heartland dan edge of heartland. Artinya terdapat kesesuaian antara karakteristik perusahaan induk, faktor sukses kritis, dan peluang-peluang pengasuhan yang ada di perusahaan anak. Dari 15 perusahaan anak yang ada, dua perusahaan anak dalam bisnis media cetak dengan nomor kode 7 dan 8 menunjukkan kinerja yang kurang baik. Studi dokumen internal perusahaan dan hasil wawancara menunjukkan bahwa perusahaan masih dalam keadaan merugi. 


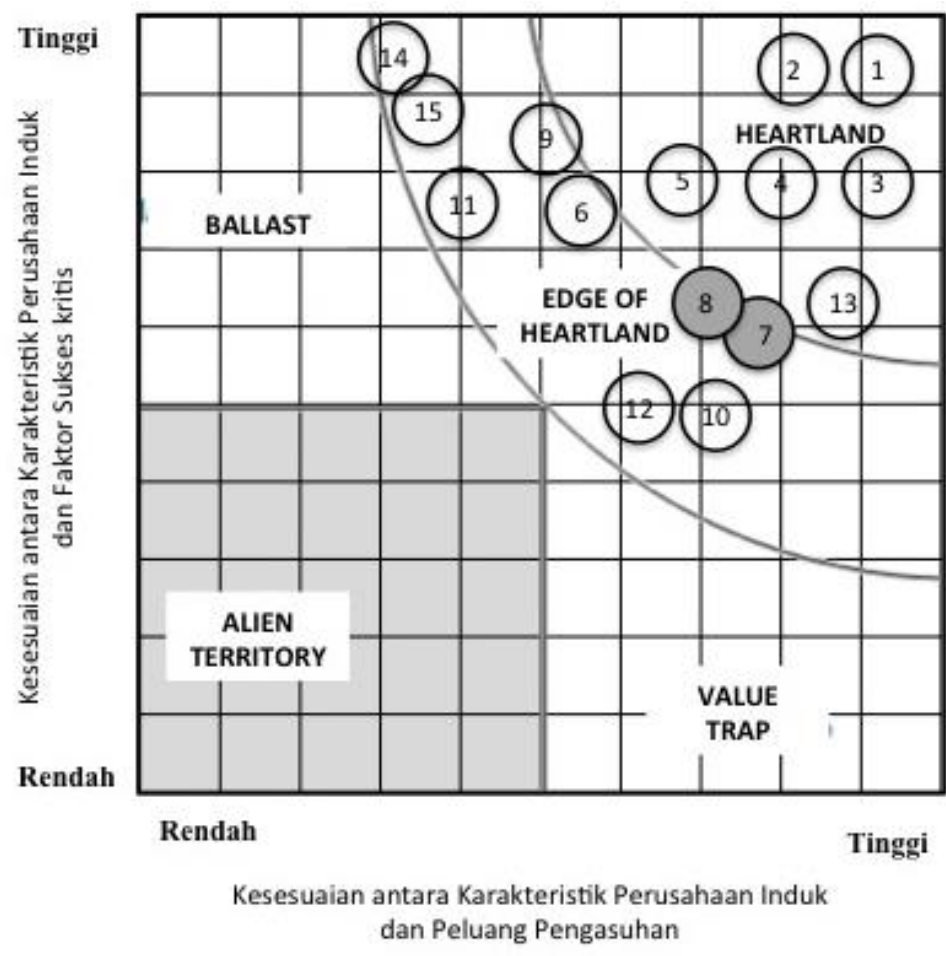

Gambar 2

Matriks Kesesuaian Pengasuhan MG

\section{Diskusi}

Studi terdahulu dari Aslibergi dan Rahmanseresht (2014); Campbell et al. (1995); juga Ciabuschi et al. (2016) menunjukkan bahwa perusahaan-perusahaan anak di kuadran heartland dan edge of heartland seharusnya dapat menunjukkan kinerja yang baik karena perusahaan induk sangat menguasai bisnisnya dan mempunyai kemampuan untuk membantu perusahaan-perusahaan anak tersebut. Pada perusahaan multibisnis MG, kinerja dua perusahaan anak dalam bisnis media cetak belum baik karena tiga hal. Pertama perusahaan-perusahaan ini baru diakuisisi oleh MG dan masih dilakukan restrukturisasi di internal perusahaan. Kedua, untuk melengkapi portofolionya dalam bisnis media cetak ini, MG masih melakukan serangkaian akuisisi media-media cetak lain. Terakhir, diakui oleh narasumber dari perusahaan anak bahwa industri media cetak pada tahun 2015 lalu tidak begitu baik pertumbuhannya, sehingga kedua perusahaan anak belum dapat menunjukkan kinerja yang memuaskan.

Hasil studi menunjukkan bahwa seluruh 15 perusahaan anak MG terletak di kuadran heartland dan edge of heartland. Hal ini disebabkan oleh karena MG dalam pertumbuhannya melakukan ekspansi bisnis ke bisnis-bisnis yang ada kaitannya dengan bisnis inti (core business) atau diversifikasi berhubungan. Sesuai studi dari Collis et al. (2012); juga Hermann (2002); Zhou (2016) dan Kownaski et al. (2013), diversifikasi berhubungan dapat dipengaruhi oleh peran kuat dari pimpinan kelompok bisnis dan jajaran eksekutif di perusahaan induk. Khususnya studi dari Hermann (2002) menunjukkan bahwa peran kuat pimpinan kelompok bisnis dapat berupa 
komposisi perusahaan anak, penetapan pimpinan-pimpinan perusahaan anak, budaya korporasi, serta pola pengendalian perusahaan induk kepada perusahaan-perusahaan anak. Zhou (2016) dalam studi terkininya menunjukkan bahwa CEO yang memiliki sebagian atau seluruh perusahaan multibisnis akan cenderung mengembangkan bisnis melalui diversifikasi berhubungan. Pertumbuhan bisnis melalui konglomerasi dipandang terlalu berisiko bagi CEO yang mempunyai kepentingan besar, seperti kepemilikan atau berusia lanjut.

Melihat pengalaman dan masa kerja CEO serta empat dari tujuh anggota dewan direksi MG, seluruhnya mengembangkan karier dan mengelola bisnis media di lingkungan MG. Di bawah pimpinan CEO, perusahaan multibisnis MG mengembangkan diri ke bisnis-bisnis yang saling berhubungan dan saling mendukung. Prahalad dan Bettis (1986) menjelaskan pengaruh logika dominan (dominant logic) atau dominasi cara berpikir pimpinan tertinggi dan jajaran eksekutif puncak mengenai strategi antar unit bisnis stratejik dan diversifikasi bisnis di perusahaan multibisnis. Perusahaan multibisnis yang dipimpin oleh anggota dewan direksi dengan multiple dominant logic, cenderung mengembangkan bisnis dengan pola konglomerasi. Sebaliknya pimpinan perusahaan multibisnis dengan kecenderungan single dominant logic akan mengembangkan bisnis dengan cara memperbesar skala bisnis tanpa melalui diversifikasi, atau melakukan diversifikasi berhubungan dengan memasuki bisnis-bisnis yang masih dikenal. Single dominant logic menurut Prahalad dan Bettis (1986) dapat terjadi bila pimpinan tertinggi dan jajaran eksekutif memiliki pengalaman yang banyak di satu industri atau banyak industri namun masih saling berhubungan. Perkembangan bisnis MG dengan mengikuti pola diversifikasi berhubungan kemungkinan sesuai dengan logika dominan direktur utama dan jajaran direksi di MG. Bila dikaitkan dengan Goold dan Campbell (2002), perusahaan-perusahaan anak di perusahaan multibisnis yang bertumbuh dengan diversifikasi berhubungan akan terletak di kuadran heartland dan edge of heartland.

Pengembangan bisnis MG melalui diversifikasi berhubungan ini tampaknya merupakan pola yang dapat ditemukan pada 12 kelompok bisnis media di Indonesia. Lim (2012) melakukan studi mengenai konsentrasi bisnis media di Indonesia yang dikuasai oleh 13 kelompok bisnis yang terdiri dari TVRI dan 12 perusahaan multibisnis milik swasta. Seluruh 12 perusahaan multibisnis tersebut mengembangkan bisnis ke aneka ragam bisnis yang saling berkaitan dengan bisnis intinya, bisnis media. Hanya lima dari 12 perusahaan multibisnis dalam studi Lim (2012) merupakan perusahaan publik. Dari laporan tahunannya, kelima perusahaan multibisnis tersebut menempatkan seluruh bisnis media di bawah satu perusahaan induk, dan bisnis-bisnis lainnya yang tak terkait bisnis media di bawah perusahaan induk berbeda. Dengan meletakkan pengelolaan perusahaan-perusahaan anak dalam bisnis yang berhubungan di bawah satu perusaan induk, kemungkinan kelima perusahaan multbisnis media di Indonesia memiliki perusahaan-perusahaan anak yang dapat ditempatkan di kuadran heartland dan edge of heartland. 


\section{SIMPULAN, KETERBATASAN DAN SARAN}

Penelitian yang dilakukan pada perusahaan multibisnis MG menunjukkan bahwa terdapat kesesuaian pengasuhan antara perusahaan induk dengan ke 15 perusahaan-perusahaan anak. Lima perusahaan anak merupakan bisnis heartland, dimana perusahaan induk sangat mengenal dan ahli dalam bisnis perusahaanperusahaan anak tersebut dan ada peluang-peluang pengasuhan yang bisa dimanfaatkan oleh perusahaan induk untuk menciptakan nilai. Empat dari lima perusahaan tersebut bergerak di bidang stasiun TV FTA yang menyumbang 90 persen pendapatan MG. Dari 11 perusahaan anak dalam kuadran edge of heartland, ada dua perusahaan anak yang memiliki kinerja kurang memuaskan. Hal ini berbeda dengan studi-studi terdahulu, disebabkan karena kedua perusahaan ini baru diakuisisi dan masih dalam proses restrukturisasi.

Penelitian ini memberikan pembelajaran bagi praktisi di dunia bisnis, khususnya perusahaan multibisnis mengenai pentingnya pemahaman mengenai kreasi nilai dan faktor-faktor yang berperan penting dalam prosesnya. Penelitian ini memiliki keterbatasan dalam tiga hal. Pertama, MG adalah perusahaan multibisnis dengan diversifikasi yang saling berhubungan (related diversification), dimana seluruh perusahaan anak beroperasi pada industri media. Sehingga tidak heran bila hasil studi menunjukkan sebaran perusahaan anak hanya pada kuadran heartland dan edge of heartland. Kedua, studi ini terutama mengandalkan wawancara dengan narasumber direksi yang hanya ditemui masing-masing dua kali selama satu hingga maksimal dua jam. Sehingga temuan-temuan kurang dapat dikaji secara lebih mendalam. Ketiga, MG merupakan perusahaan yang melakukan pertumbuhan melalui serangkaian akuisisi. Saat penelitian dilakukan, perusahaan induk dalam proses melakukan akuisisi terhadap beberapa perusahaan dan melakukan restrukturisasi di internal perusahaan anak serta kelompok bisnisnya. Hal ini membuat beberapa temuan hasil penelitian menjadi tidak relevan lagi.

Seperti pada penelitian yang mengikuti pendekatan kualitatif, hasil studi penelitian ini tidak dapat digeneralisasi, karena memang bukan itu tujuannya. Penelitian ini mengandalkan terutama pada hasil wawancara dengan nara sumber yang dipilih karena posisi atau otoritas dalam perusahaan yang dipimpinnya, pengalaman manajerial, dan pengetahuan lintas perusahaan anak. Kesibukan nara sumber menjadi kendala utama pengumpulan informasi sehingga wawancara hanya dilakukan maksimal dua kali. Kesibukan nara sumber juga berpengaruh pada keseluruhan proses pengambilan data yang memakan waktu hampir tujuh bulan, dimana selama itu terjadi aksi-aksi korporasi yang bisa mempengaruhi hasil penelitian.

Untuk melengkapi hasil penelitian ini disarankan agar dilakukan penelitian lebih lanjut dalam hal peran direktur utama (CEO) dalam kreasi nilai di perusahaan multibisnis. Selain itu, dapat dilakukan penelitian mengenai perbedaan kesesuaian 
pengasuhan antara perusahaan multibisnis dengan diversifikasi berhubungan (related diversification) dan tidak berhubungan (unrelated diversification, conglomeration).

\section{DAFTAR PUSTAKA}

Afza, T., C. Slahudin, dan M. S. Nazir. 2008. "Diversification and corporate performance: an evaluation of Pakistani firms". South Asian Journal of Management 15(3):7-18.

Aslibeigi, M., dan H. Rahmanseresht. 2014. "Evaluating the fit of the parent company with businesses to develop corporate strategy (Case study: ICKO employees cooperative) ". Malaysian Management Journal 18: 23-38.

Basu, N. 2010. "Trends in corporate diversification”. Financial Markets and Portfolio Management 24(1): 87-102.

Baxter, P., dan S. Jack. 2008. "Qualitative case study methodology: study design and implementation for novice researchers". The Qualitative Report 13(4): 544559.

Bennet, A., dan C. Elman. 2006. "Qualitative research: recent development in case study methods”. Annual review of Political Science 9: 455-476.

Campbell, A., M. Goold, dan M. Alexander. 1995. “Corporate strategy: The quest for parenting advantage”. Harvard Business Review (March-April): 120-132.

Chan-Olmsted, S. M., dan B. Chang. 2003. "Diversification strategy of global media conglomerates: examining its patterns and determinants ". Journal of Media Economics 16(4): 213-233.

Ciabuschi, F., M. Forsgren, dan O. Martin. 2016. "Value creation at the subsidiary level: testing the MNC headquarters parenting advantage logic”. Long Range Planning 50(1): 48-62.

Collis, D., D. Young, dan M. Goold. 2012. “The size and composition of corporate headquarters in multinational companies: empirical evidence". Journal of International Management 18(3): 260-275.

Goold, M., dan M. Campbell. 2002. "Parenting in complex structure”. Long Range Planning 35(3): 219-243.

Gummeson, S. 2006. "Qualitative research in management:addresing complexity, content, and persona”. Management Decision 44(2): 167-179.

Hermann, P. 2002. "The influence of CEO characteristics on the international diversification of manufacturing firms: An empirical study in the United States”. International Journal of Management 19(2): 279-289. 
Kownatzki, M., Walter, J., Floyd, S.W., dan Lechner, C. 2013. "Corporate control and the speed of strategic business unit decision making". Academy of Management Journal 56(5): 1295-1324. DOI: 10.5465/amj.2011.0804

Kruehler, M., Pidun, U., dan Rubner, H. 2012. "How to assess the corporate parenting strategy? A conceptual answer”. Journal of Business Strategy 33(4): 4-17. DOI: $10.1108 / 02756661211242663$

Landau, C., dan C. Bock. 2013. "Value creation through vertical intervention of corporate centers in single business units of unrelated diversified portfolios the case of private equity firms ”. Long Range Planning 46(1-2): 97-124.

Lim, M. 2012. “The League of thirteen: Media concentration in Indonesia”. Research report. Tempe, AZ: Participatory Media Lab at Arizona State University. Ford Foundation.

Martin, J. A., dan K. M. Eisenhardt. 2010. "Rewiring: Cross-business-unit collaborations in multibusiness organizations". Academy of Management Journal 53(2): 265-301.

Menz, D., M. Kunisch, dan S. Collis. 2015. "The corporate headquarters in the contemporary corporation: advancing a multimarket firm perspective". Academy of Management Annals 9(1): 633-714.

Munir, N. S. 2010. "Kesesuaian pengasuhan (parenting fit) di perusahaan multi bisnis: studi kasus kelompok "transportasi." "Journal of Business Strategy and Execution 2(2): 126-156.

Prahalad, C. K. dan R. Bettis. 1986. "The dominant logic: a new linkage between diversity and performance”. Strategic Management Journal 7(6): 485-501.

Ramaswamy, K., M. Li, dan B. Petitt. 2004. ”Who drives unrelated diversification? A study of Indian manufacturing firms". Asia Pacific Journal of Management 21(4) : 403-423.

Sekulic, V., 2009. "Corporate strategy development and competitive advantage of enterprise”. Economics and Organization 6(3): 269 - 279.

Stake, R. 1995. "The art of case study research". Thousand Oaks, CA: Sage Publications.

Swaminathan, V., F. Murshed, dan J. Hulland. 2008. "Value creation following merger and acquisition announcements: the role of strategic emphasis alignment". Journal of Marketing Research 45(1): 33-47.

Yin, R. K. 2002. “Case study research: Design and methods”. Thousand Oaks, CA: Sage Publications. 
Zhou, J. 2016. "Sources of CEO power and firm diversification: how threat plays a role". Annual Meeting of the Academy of Management, Anaheim, California, 5-9 August 2016. 
Volume 20 No. 2, Oktober 2017

ISSN 1979 - 6471 